\title{
KOHERENSI PENGATURAN ILLEGAL, UNREPORTED, AND UNREGULATED FISHING DI INDONESIA
}

\author{
(Coherency Arrangement For Illegal, Unreported, And Unregulated Fishing In Indonesia)
}

\author{
Muhammad Fatahillah Akbar \\ Fakultas Hukum Universitas Gadjah Mada Yogyakarta \\ Jalan Sosio Yustisia Bulaksumur Nomor 1, Depok, Daerah Istimewa Yogyakarta \\ Email: muhfatahillahakbar@gmail.com
}

Naskah diterima: 11 Juni 2019; revisi: 29 Juli 2019; disetujui: 2 Agustus 2019

\begin{abstract}
Abstrak
Sumber daya hayati perikanan adalah sumber daya yang perlu dilindungi dan dioptimalkan pengolahannya, namun kejahatan di bidang perikanan semakin meningkat. Hukum internasional kemudian mengklasifikasikan kejahatan perikanan ke dalam Illegal, Unreported, and Unregulated Fishing. Pertanyaan dalam penelitian ini adalah bagaimana koherensi hukum nasional Indonesia di bidang perikanan dengan hukum internasional. Hal ini penting karena kejahatan di bidang perikanan memiliki banyak aspek internasional. Penelitian ini bertujuan untuk mengkaji koherensi hukum nasional dan internasional dalam menanggulangi kejahatan di bidang perikanan, serta mengusulkan reformulasi peraturan perundang-undangan dalam menangani permasalahan tersebut. Metode penelitian yang digunakan adalah normatif-yuridis dengan membandingkan peraturan hukum nasional dan peraturan hukum internasional di bidang perikanan. Penelitian ini menunjukkan bahwa koherensi hukum nasional dan internasional di bidang perikanan ini cukup baik. Namun, terdapat beberapa kelemahan berupa tidak adanya pengaturan unreported fishing, pertanggungjawaban korporasi yang lemah, pengaturan di laut lepas, dan kerjasama dengan WCPFC. Dalam hal ini reformulasi ditujukan untuk memperbaiki kekurangan-kekurangan tersebut untuk mengoptimalkan perlindungan dan pemanfaatan sumber daya hayati perikanan.
\end{abstract}

Kata Kunci: koherensi, IIU fishing, kejahatan di bidang perikanan

\begin{abstract}
Fishery resources is a resource which shall be protected and optimized. However, fishery crimes increase. Then, international law classifies fishery crimes to Illegal, Unreported, and Unregulated Fishing. The question is how coherent Indonesian law and international on fishery laws. It is important because the fishery crimes relate to many international aspects. This research aims to examine the coherency between Indonesian law and international law in eradicating fishery crime and also the reformulation of Indonesian law on fisheries to optimize the protection. This research shows that Indonesian law has been sufficiently coherent with international aspect in some extents. However, there are still lack of development in some areas including, the absence of unreported fishing in Indonesian law, the weak regulation on corporate responsibility, and the lack of regulation on cooperation with WCPFC. In this matters, the reformulation of the law will fix those problems to optimize the protection and the use of fishery resources.
\end{abstract}

Keywords: coherency, illegal, unreported, and unregulated fishing, crimes in fisheries 


\section{A. Pendahuluan}

Indonesia merupakan negara kepulauan yang sebagian besar wilayahnya adalah perairan. Potensi sumber daya hayati di bidang perikanan Indonesia sangatlah potensial dalam mengembangkan perekonomian Indonesia. Dalam hal ini perikanan lepas pantai atau yang biasa disebut offshore fisheries merupakan jenis yang dapat memakmurkan industri perikanan. ${ }^{1}$ Oleh karena itu, pemberdayaan sumber daya hayati tersebut adalah keniscayaan. Namun, pelanggaran terhadap pengelolaan sumber daya tersebut diperkirakan telah merugikan Indonesia sebesar 1,9 triliun rupiah per tahun. $^{2}$

Apabila diakumulasikan keseluruhan hasil tangkapan ikan yang tergolong dalam pelanggaran atau kejahatan di bidang perikanan, terlihat jelas bahwa kerugian yang dialami Indonesia sangat signifikan. Berdasarkan hasil penelitian global diperkirakan pelanggaran di bidang perikanan mencapai $30-40 \%$ dari hasil tangkapan total. Dalam definisi kegiatan ilegal pencurian ikan dimasukkan pula kategori hasil tangkapan yang tidak dilaporkan (unreported), termasuk di dalamnya hasil tangkapan sampingan (by catch) dan kegiatan perikanan yang tidak diatur dalam sistem peraturan dan perundang-undangan. ${ }^{3}$ Saat ini pelanggaran di bidang perikanan sudah mulai diklasifikasikan sebagai Illegal, Unreported, and Unregulated Fishing (IUU Fishing).
IUU Fishing adalah terminologi umum untuk menunjukkan permasalahan internasional di bidang perikanan yang melanggar tatanan peraturan baik dalam lingkup nasional maupun internasional. ${ }^{4}$ IUU Fishing biasanya dilakukan dengan melanggar berbagai peraturan di bidang perikanan, seperti kuota penangkapan ikan, perusakan wilayah perairan, dan berbagai pelanggaran hukum lainnya. ${ }^{5}$ Hal ini kemudian menjadi permasalahan yang harus diselesaikan tidak hanya dalam lingkup internasional, namun juga dalam lingkup nasional. Begitu maraknya penangkapan ikan yang eksploitatif dan tidak memperhatikan pelestarian sumber daya ikan yang ada, Food and Agricultural Organization (FAO) merupakan Badan Khusus PBB yang menangani makanan dan pertanian telah mengeluarkan beberapa Code of Conduct for Responsible Fisheries 1995 (CCRF) dan International Plan of Action to Prevent, Deter and Eliminate Illegal, Unreported and Unregulated Fishing. (IPOA-IUU Fishing) Bahkan pada tingkat regional juga sudah ada Regional Plan of Action on Promoting Responsible Fishing Practice including Combating IUU-Fishing in Region 2007.

Program aksi internasional yang diintrodusir FAO menjelaskan tujuan dan prinsip-prinsip serta implementasi dan upaya mencegah, menghambat dan menghapus Illegal, Unreported dan Unregulated Fishing, Upaya difokuskan pada pengaturan tanggung jawab semua Negara, dalam hal ini yaitu 
Negara bendera kapal, Negara pantai, Negara pelabuhan tempat pendaratan kapal yang menangkap ikan serta upaya yang berkaitan dengan pasar yang disepakati secara internasional. Luasnya wilayah perairan Indonesia yang meliputi perairan pedalaman, laut teritorial, jalur tambahan dan wilayah zona ekonomi eksklusif Indonesia rawan terhadap IUU fishing.

Pada dasarnya Indonesia telah memiliki aturan hukum yang cukup komprehensif mengenai penegakan hukum di bidang perikanan. Undang-Undang Nomor 31 Tahun 2004 tentang Perikanan dan Undang-Undang Nomor 45 Tahun 2009 tentang Perubahan Undang-Undang Nomor 31 Tahun 2004 tentang Perikanan merupakan peraturan perundang-undangan pokok di bidang perikanan.

Tindak Pidana di bidang perikanan diatur dengan cukup komprehensif dalam UndangUndang Nomor 31 Tahun 2004 tentang Perikanan tersebut. Pengaturannya mulai dari penangkapan ikan yang tidak sah, penangkapan ikan dengan menggunakan peralatan berbahaya, hingga dengan perusakan lingkungan perairan. Terlebih, dibentuk suatu kapal pengawas perikanan. Undang-Undang Nomor 45 Tahun 2009 tentang Perubahan Undang-Undang Nomor 31 Tahun 2004 tentang Perikanan memberikan kewenangan tambahan untuk menenggelamkan kapal perikanan berbendera asing berdasarkan bukti permulaan yang cukup. ${ }^{6} \mathrm{Hal}$ ini tentu menjadi perhatian menarik bagi dunia Internasional, terutama mengenai apakah dapat dibenarkan kewenangan tersebut yang diberikan kepada kapal pengawas perikanan jika dilihat dari Aksi Internasional yang dirancang FAO.

Perairan dunia saat ini telah kehilangan 74 persen keluarga ikan yang telah menjadi makanan sehari-sehari, seperti tuna, makarel, dan bonito. Hal ini berarti sudah banyak ikan yang berkurang dari perairan di dunia. ${ }^{7} \mathrm{Hal}$ ini disebabkan salah satunya adalah penegakkan hukum perikanan di Indonesia. Padahal menurut pasal 69 Ayat (4) Undang-Undang Nomor 45 Tahun 2009, dalam melaksanakan fungsinya, penyidik dan/ atau pengawas perikanan dapat melakukan tindakan khusus berupa pembakaran dan/ atau penenggelaman kapal perikanan yang berbendera asing berdasarkan bukti permulaan yang cukup. Untuk melaksanakan penegakan hukum perikanan yang baik, Kementerian Kelautan dan Perikanan telah melakukan sekuritisasi isu IUU Fishing dengan melakukan berbagai publikasi dan sosialisasi mengenai dampak dari IUU Fishing terhadap kedaulatan Indonesia. ${ }^{8}$

Sekuritisasi adalah bentuk adopsi Rencana Aksi Internasional terhadap dalam menanggulangi IUU Fishing di Indonesia. Namun, yang menjadi pertanyaan apakah dalam peraturan perundang-undangan di Indonesia telah sejalan dengan Rencana Aksi internasional tersebut. Hal ini ditunjukkan dengan signifikansi pemberantasan tindak pidana di bidang perikanan yang telah mencapai level internasional.

Pasal 69 ayat (4) Undang-Undang Nomor 31 Tahun 2004 tentang Perikanan

Hanuring Ayu, "Government Policy Directions on Illegal Unreported Unregulated (IUU) Fishing in Indonesia", (Proceeding: Internationalization of Islamic Higher Education Institutions Toward Global Competitiveness, Semarang, 20-21 September 2018), hlm 107.

8 Ibid. 
Dalam hal ini perlu dikaji bagaimanakah kesesuaian antara pidana perikanan di tingkat nasional dengan aksi internasional tersebut. Hal tersebut merupakan landasan diselenggarakannya penelitian dengan topik "Sinkronisasi Rencana Aksi Internasional tentang Illegal, Unreported, and Unregulated Fishing dengan Penegakan Hukum Pidana Perikanan di Indonesia". Permasalahan yang diangkat dalam artikel ini adalah: (1) Bagaimana koherensi hukum internasional mengenai IUU Fishing dengan Penegakan Hukum Pidana Perikanan di Indonesia? (2) Bagaimana desain pengaturan penegakan hukum perikanan yang tepat untuk Indonesia dalam menangani permasalahan IUU Fishing?

\section{B. Metode Penelitian}

Metode penelitian adalah suatu pendekatan umum ke arah fenomena yang telah dipilih oleh peneliti untuk diselidiki. Hal ini berarti bahwa metode penelitian merupakan sejenis logika yang mengarahkan penelitian. Pengertian metode penelitian tersebut sesuai dengan hakikat penelitian sebagai suatu penemuan informasi melalui prosedur tertentu atau prosedur terstandar. ${ }^{9}$ Bertolak dari uraian di atas metode penelitian yang dipilih dan digunakan dalam penelitian ini mencakup jenis penelitian, bahan penelitian, alat penelitian, jalannya penelitian, maupun analisis data.

Penelitian hukum sebagai bagian dari penelitian pada umumnya dapat dibedakan jenisnya menurut sumber data, sifat, maupun bentuknya. Dalam kerangka demikian, apabila penelitian hukum dilihat dari sumber datanya, maka penelitian hukum dapat dibedakan menjadi penelitian hukum normatif dan penelitian hukum empiris. Penelitian hukum normatif merupakan penelitian hukum yang lebih mengutamakan pada penggunaan data sekunder, sedangkan penelitian hukum empiris merupakan penelitian hukum yang menekankan pada penggunaan data primer. $^{10}$

Apabila penelitian hukum dilihat dari sifatnya, maka penelitian hukum dapat dibagi menjadi penelitian eksploratoris, penelitian deskriptif, dan penelitian eksplanatoris. Penelitian eksploratoris merupakan penelitian yang dilakukan apabila pengetahuan tentang suatu gejala yang akan diselidiki masih kurang sekali atau bahkan tidak ada. Penelitian deskriptif merupakan penelitian yang dimaksudkan untuk memberikan data yang seteliti mungkin tentang manusia, keadaan atau gejala-gejala lainnya. Sedangkan penelitian eksplanatoris merupakan penelitian yang dimaksudkan untuk menguji hipotesa-hipotesa tertentu apabila pengetahuan tentang suatu masalah sudah cukup. ${ }^{11}$

Apabila penelitian hukum dilihat dari bentuknya, maka penelitian hukum dapat dibagi menjadi penelitian diagnostik, penelitian preskriptif dan penelitian evaluatif. Penelitian diagnostik merupakan penelitian yang dimaksudkan untuk mendapatkan informasi mengenai penyebab terjadinya suatu gejala. Penelitian preskriptif merupakan penelitian yang ditujukan untuk mendapatkan saran-saran mengenai apa yang harus 
dilakukan dalam mengatasi masalah-masalah tertentu. Sedangkan penelitian evaluatif merupakan penelitian yang dilakukan untuk menilai program-program yang dijalankan. ${ }^{12}$

Bertolak dari pembedaan penelitian hukum di atas, apabila penelitian ini dilihat dari sumber datanya, maka penelitian ini merupakan penelitian hukum normatif. Hal tersebut didasarkan pada pertimbangan bahwa penelitian ini menekankan pada penggunaan data sekunder untuk mengkaji koherensi hukum pidana nasional dan hukum pidana internasional. Dalam hal ini tentu, sumber hukum primer dan sumber hukum sekunder menjadi patokan dasar. Berkaitan dengan penelitian hukum normatif, Soerjono Soekanto dan Sri Mamudji pernah mengemukakan bahwa penelitian hukum normatif atau penelitian hukum kepustakaan dapat mencakup penelitian terhadap asasasas hukum, penelitian terhadap sistematik hukum, penelitian terhadap taraf sinkronisasi vertikal dan horizontal, perbandingan hukum, dan sejarah hukum. ${ }^{13}$ Dalam kerangka demikian, penelitian ini merupakan penelitian dengan menggunakan perbandingan hukum yang tujuannya membandingkan hukum pidana nasional dan internasional di bidang perikanan. Oleh karena itu, harus dilakukan inventarisasi terlebih dahulu berbagai Peraturan Perundang-undangan di Bidang perikanan dan inventarisasi hukum internasional di bidang perikanan.

Apabila penelitian ini dilihat dari sifatnya, maka penelitian ini dapat dikualifikasikan sebagai penelitian preskriptif. Hal tersebut didasarkan pada pertimbangan bahwa penelitian ini dimaksudkan untuk mencari saran perbaikan untuk hukum yang di bidang perikanan dengan cara melihat kekuatan dan kelemahan hukum nasional dibandingkan dengan hukum internasional di bidang perikanan.

\section{Pembahasan}

\section{Koherensi Pidana Perikanan Nasional dengan Hukum Internasional}

\section{a. Urgensi Koherensi}

Perkembangan kejahatan tidak dapat dilepaskan dari pengaruh globalisasi. ${ }^{14}$ Globalisasi mengembangkan teknologi yang memperbanyak variasi modus operandi kejahatan. ${ }^{15}$ Selain berpengaruh pada modus operandi, Globalisasi juga menciptakan fenomena borderless dimana batas antar negara semakin tidak nyata. ${ }^{16}$ Dalam fenomena tersebut tentu penegakan hukum menjadi sulit. Dalam hal ini hukum pidana internasional dibutuhkan untuk menanggulangi fenomena borderless tersebut.

Menurut Cherif Bassiouni sebagaimana dikutip Eddy Hiariej, pengertian hukum pidana internasional adalah terdapat dua dimensi, yakni aspek-aspek pidana dalam hukum internasional dan aspek-aspek internasional dalam hukum pidana. ${ }^{17}$ Pada pengelolaan perikanan antar negara baik dalam Zona Ekonomi Ekslusif (ZEE), maupun dalam laut bebas tentu pelanggaran yang ada di

\footnotetext{
Ibid.

13 Soerjono Soekanto dan Sri Mamudji, Penelitian Hukum Normatif Suatu Tinjauan Singkat, (Jakarta ,Rajawali Press 2001), hlm 14.

14 Romli Atmasasmita, Globalisasi dan Kejahatan Bisnis, (Jakarta, Kencana 2010), hlm 28.

15 Ibid.

16 Ibid

17 Eddy O.S. Hiariej, Pengantar Hukum Pidana Internasional, (Jakarta, Erlangga 2009), hlm 8.
} 
dalamnya akan membuat penegakan hukum terhadap situasi menjadi kompleks. Situasi tersebut tentu dapat dikatakan sebagai aspek internasional dalam hukum pidana dimana hukum pidananya berdasarkan hukum nasional, namun penegakkannya memerlukan kerjasama internasional.

Fenomena borderless dan globalisasi sangat berpengaruh dalam perkembangan pengelolaan perikanan di Indonesia. Hal ini ditunjukkan dalam United Nations Convention on Law of Sea (UNCLoS) yang telah diratifikasi pada tanggal 31 Desember 1985 melalui Undang-Undang Nomor 17 Tahun 1985 dimana Indonesia menjadi Negara ke-26 yang meratifikasi konvensi tersebut. Pasal 62 UNCLoS mengatur bahwa Negara pihak harus mengoptimalkan sumber daya hayati di dalam Zona Ekonomi Ekslusif negaranya. ${ }^{18} \mathrm{Jika}$ negara tersebut tidak mampu, maka negara tersebut harus memberikan kesempatan pada negara lain untuk memanfaatkan sumber daya hati pada wilayah ZEE negara tersebut. ${ }^{19}$ Dalam memberikan akses kepada negara lain sebagaimana dimaksud pada Pasal 62 tersebut, pemberian akses harus didasarkan pada beberapa pertimbangan, seperti seberapa penting sumber daya hayati dalam ZEE tersebut bagi perkembangan perekonomian negara yang bersangkutan. ${ }^{20}$

Hal ini menunjukkan bahwa penegakan hukum pidana perikanan harus berkesinambungan dengan hukum internasional yang telah disepakati oleh Indonesia dan negara lain, baik bersifat bilateral, regional, maupun multilateral. Dalam hal ini koherensi hukum nasional dan internasional sangat dibutuhkan dalam menanggulangi kompleksitas penegakan hukum pidana perikanan. Terlebih Indonesia memiliki wilayah perairan 2/3 dari total wilayah Indonesia. Hal ini menjadikan Indonesia bersinggungan dengan negaranegara tetangga dalam pengelolaan sumber daya hayati. Hal ini tentu memerlukan perjanjian antar wilayah pengelolaannya.

Selain sebagai penyelesaian penegakan hukum, koherensi hukum internasional dan hukum nasional adalah bertujuan untuk mempertahankan reputasi internasional Negara Indonesia dalam memberantas tindak pidana perikanan. Hal ini juga merupakan salah satu aspek penting dalam politik internasional Indonesia. ${ }^{21}$ Pengaturan lebih lanjut mengenai pidana perikanan dalam hukum internasional ke dalam hukum nasional dibutuhkan untuk menjaga reputasi tersebut.

Seberapa jauh koherensi yang harus diikuti harus juga dijawab dalam kajian ini. Setidaknya secara materiil perbuatanperbuatan yang dianggap sebagai kejahatan di bidang perikanan dalam hukum internasional harus dapat disesuaikan dalam hukum nasional. Hal ini tentu untuk memberikan persamaan pengaturan antar negara-negara mengenai perbuatan yang dianggap sebagai sebuah kejahatan. Hal ini

18 Pasal 62 Undang-Undang Nomor 31 Tahun 2004 Tentang Perikanan (Lembaran Negara Republik Indonesia Tahun 2004 Nomor 118) jo Undang-Undang Nomor 45 Tahun 2009 Tentang Perubahan Atas Undang-Undang Nomor 31 Tahun 2004 Tentang Perikanan (Lembaran Negara Republik Indonesia Tahun 2009 Nomor 154).

19 Pasal 62 Undang-Undang Nomor 31 Tahun 2004 Tentang Perikanan (Lembaran Negara Republik Indonesia Tahun 2004 Nomor 118) jo Undang-Undang Nomor 45 Tahun 2009 Tentang Perubahan Atas Undang-Undang Nomor 31 Tahun 2004 Tentang Perikanan (Lembaran Negara Republik Indonesia Tahun 2009 Nomor 154).

20 Rudy Satriyo Mukantardjo, dkk, Op.cit., hlm.91.

21 Eddy O.S. Hiariej, Op.cit., hlm 41. 
berkaitan dengan double criminality principle dimana suatu perbuatan dinyatakan sebagai perbuatan pidana pada negara-negara yang sedang bernegosiasi dalam ekstradisi. Hal ini menjawab bahwa koherensi di bidang pidana materiil adalah sangat penting. Hal ini berkaitan dengan aspek-aspek pidana dalam hukum internasional.

Selain itu, koherensi di dalam penegakan hukum atau hukum acara pidana perikanan juga sangat dibutuhkan. Sekalipun pidana materiil telah koheren, namun penegakkannya tidak koheren maka akan tetap ditemui berbagai perkara perikanan yang tidak dapat diselesaikan ketika telah melibatkan aspek internasional. Kesinambungan hukum acara pidana di bidang perikanan ini sangat penting dalam hal mempermudah penegakan hukum. Selain itu, hal ini juga dapat membangun kerjasama internasional dalam pemberantasan pidana perikanan. Hal ini berkaitan dengan aspek-aspek internasional dalam hukum pidana.

\section{b. Koherensi Hukum Materiil}

Dalam hukum nasional sumber hukum utama di bidang perikanan adalah UndangUndang Perikanan. Pada Undang-Undang Nomor 31 Tahun 2004 tentang Perikanan, sebagaimana telah diubah dengan UndangUndang Nomor 45 Tahun 2009 tentang Perikanan.

Sebelum membahas koherensi di dalam bidang yang lebih spesifik yakni perbuatan pidana, koherensi secara umum terlebih dahulu akan ditunjukkan. Dalam hal ini dapat dimulai dengan ruang lingkup pemberlakuan
UU Perikanan. Pasal 4 UU Perikanan menyatakan: ${ }^{22}$

Undang-undang ini berlaku untuk:

a) setiap orang, baik warga negara Indonesia maupun warga negara asing dan badan hukum Indonesia maupun badan hukum asing, yang melakukan kegiatan perikanan di wilayah pengelolaan perikanan Republik Indonesia;

b) setiap kapal perikanan berbendera Indonesia dan kapal perikanan berbendera asing, yang melakukan kegiatan perikanan di wilayah pengelolaan perikanan Republik Indonesia;

c) setiap kapal perikanan berbendera Indonesia yang melakukan penangkapan ikan di luar wilayah pengelolaan perikanan Republik Indonesia; dan

d) setiap kapal perikanan berbendera Indonesia yang melakukan penangkapan ikan, baik sendiri-sendiri maupun bersama-sama, dalam bentuk kerja sama dengan pihak asing.

Ketentuan ruang lingkup tersebut menunjukkan bahwa ruang lingkup UU Perikanan berkaitan dengan subjek "kapal berbendera negara Indonesia" dan "kapal berbendera negara asing" yang melakukan kegiatan perikanan dalam wilayah "pengelolaan perikanan Republik Indonesia." Pasal 5 ayat (1) UU Perikanan mendefinisikan wilayah pengelolaan perikanan Republik Indonesia meliputi: a. perairan Indonesia; b. ZEEI; dan c. sungai, danau, waduk, rawa, dan genangan air lainnya yang dapat diusahakan sertalahan pembudidayaan ikan yang potensial

22 Pasal 4 Undang-Undang Nomor 31 Tahun 2004 Tentang Perikanan (Lembaran Negara Republik Indonesia Tahun 2004 Nomor 118) jo Undang-Undang Nomor 45 Tahun 2009 Tentang Perubahan Atas Undang-Undang Nomor 31 Tahun 2004 Tentang Perikanan (Lembaran Negara Republik Indonesia Tahun 2009 Nomor 154). 
di wilayah Republik Indonesia. ${ }^{23}$ Dalam hal ini, telah terdapat ketidak sesuaian dengan IPOAIUU. Poin 10-12 IPOA-IUU mengatur mengenai pengaturan kapal berbendera negara dalam perairannya. ${ }^{24}$ Sedangkan, Poin 14 IPOA-IUU mengatur mengenai kapal berbendera negara yang mengatur dalam laut lepas. ${ }^{25}$ Dalam hal ini, UU Perikanan tidak mengatur bagaimana pengaturan terhadap kapal berbendera negara Indonesia di laut lepas. Dalam hal ini, Indonesia tidak terlibat dalam perlindungan perikanan di laut lepas.

Setelah mengkaji koherensi dalam bidang ruang lingkup, maka perlu dikaji ketentuan pidananya. Bab XV Undang-Undang Nomor 31 Tahun 2004 tentang Perikanan (UU Perikanan) memuat ketentuan pidana. Dalam Ketentuan Pidana tersebut, Perbuatan Pidana diatur dalam Pasal 84 sampai dengan Pasal 100 UU Perikanan. Untuk mempermudah dan menyederhanakan kajian ini maka kajian akan difokuskan pada Kejahatan di Bidang Perikanan, hal ini karena pelanggaran di bidang perikanan lebih bersifat ringan.

Klasifikasi pelanggaran dan kejahatan tidak diberikan dalam semua Undang-Undang Pidana Khusus. Namun, UU Perikanan memuat klasifikasi tersebut sebagaimana diatur Pasal 103 yang menyatakan: ${ }^{26}$
(1) "tindak pidana sebagaimana dimaksud dalam Pasal 84, Pasal 85, Pasal 86, Pasal 88, Pasal 91, Pasal 92, Pasal 93 dan Pasal 94 adalah kejahatan"

(2) "tindak pidana sebagaimana dimaksud dalam Pasal 87, Pasal 89, Pasal 90, Pasal 95, Pasal 96, Pasal 97, Pasal 98, Pasal 99, dan Pasal 100 adalah pelanggaran".

Klasifikasi tersebut menunjukkan bahwa terdapat 8 Kejahatan di Bidang Perikanan dan 9 Pelanggaran di bidang perikanan. Untuk mempermudah maka akan dilakukan kajian terhadap tiap-tiap kejahatan di bidang perikanan,

Pasal 84 mengatur perbuatan pidana yang dirumuskan sebagai berikut:

1) Setiap orang yang dengan sengaja di wilayah pengelolaan perikanan Republik Indonesia melakukan penangkapan ikan dan/atau pembudidayaan ikan dengan menggunakan bahan kimia, bahan biologis, bahan peledak, alat dan/atau cara, dan/ atau bangunan yang dapat merugikan dan/atau membahayakan kelestarian sumber daya ikan dan/ atau lingkungannya sebagaimana dimaksud dalam Pasal 8 ayat (1), dipidana dengan pidana penjara paling lama 6 (enam) tahun dan denda paling banyak Rpl.200.000.000,00 (satu miliar dua ratus juta rupiah). ${ }^{27}$

3 Pasal 5 ayat (1) Undang-Undang Nomor 31 Tahun 2004 Tentang Perikanan (Lembaran Negara Republik Indonesia Tahun 2004 Nomor 118) jo Undang-Undang Nomor 45 Tahun 2009 Tentang Perubahan Atas Undang-Undang Nomor 31 Tahun 2004 Tentang Perikanan (Lembaran Negara Republik Indonesia Tahun 2009 Nomor 154).

24 Poin 10=12, International Plan of Action to Prevent, Deter, and Eliminate Illegal, Unreported, and Unregulated Fishing.

25 Poin 14 International Plan of Action to Prevent, Deter, and Eliminate Illegal, Unreported, and Unregulated Fishing.

26 Pasal 103 ayat (1) dan (2) Undang-Undang Nomor 31 Tahun 2004 Tentang Perikanan (Lembaran Negara Republik Indonesia Tahun 2004 Nomor 118)

27 Pasal 84 ayat (1) Undang-Undang Nomor 31 Tahun 2004 Tentang Perikanan (Lembaran Negara Republik Indonesia Tahun 2004 Nomor 118) jo Undang-Undang Nomor 45 Tahun 2009 Tentang Perubahan Atas Undang-Undang Nomor 31 Tahun 2004 Tentang Perikanan (Lembaran Negara Republik Indonesia Tahun 2009 Nomor 154). 
Pasal 84 memiliki 4 ayat yang pada dasarnya rumusan actus reus nya sama, namun hanya dibedakan subjek yang melakukan. Pada Pasal 84 ayat 1 bersifat lebih umum dengan rumusan "setiap orang", namun ayat (2) memberikan spesifikasi pada "Nakhoda atau pemimpin kapal perikanan, ahli penangkapan ikan, dan anak buah kapal"28, kemudian ayat (3) memberikan spesifikasi subjek "Pemilik kapal perikanan, pemilik perusahaan perikanan, penanggung jawab perusahaan perikanan, dan/atau operator kapal perikanan"29, dan ayat (4) merumuskan "Pemilik perusahaan pembudidayaan ikan, kuasa pemilik perusahaan pembudidayaan ikan, dan/atau penanggung jawab perusahaan pembudidayaan ikan". ${ }^{30}$ Dengan pembedaan tersebut maka berlaku asas lex specialis derogate legi generalis dimana ketika terdapat subjek yang dengan sengaja melakukan penangkapan ikan menggunakan barang yang dilarang memenuhi subjek hukum tertentu sebagaimana diatur dalam Pasal 84 ayat 2, 3, atau 4 maka yang berlaku adalah ayat-ayat tersebut. Pengaturan secara khusus tersebut dinilai sangat baik, karena sebelumnya pada UU Perikanan tahun 1985 dalam praktiknya sulit sekali menjerat pemilik perusahaan perikanan, sedangkan pelaku lapangan banyak yang tertangkap walaupun mereka hanya menjalankan perintah atasan. ${ }^{31}$

Di bidang perikanan, prinsip pertanggungjawaban korporasi tidak begitu populer dalam penanganan kasus-kasus tindak pidana perikanan. Meski Undang-Undang Nomor 9 Tahun 1985 tentang Perikanan mengakui adanya "Badan Hukum" (di samping orang perorangan) sebagai subjek hukum dalam tindak pidana perikanan, namun undangundang tersebut tidak mengatur lebih lanjut kapan suatu badan hukum dikatakan melakukan tindak pidana, dan siapa yang dapat dipertanggungjawabkan atas tindak pidana tersebut. ${ }^{32}$ Akibatnya penanganan kasus-kasus tindak pidana perikanan sulit "dituntaskan", khususnya yang melibatkan pihak korporasi. Pada banyak kasus, mereka yang diseret ke pengadilan hanya pelaku di lapangan seperti nakhoda kapal, kepala kamar mesin (KKM), dan anak buah kapal (ABK), sedangkan pihak-pihak yang berada di belakang mereka (korporasi) nyaris tidak pernah tersentuh. ${ }^{33}$ Namun, penyempurnaan pertanggungjawaban ini tidak dilakukan dengan optimal. Hal ini ditutupi dengan adanya ketentuan dalam Pasal 101 UU Perikanan yang menyatakan "dalam hal tindak pidana perikanan dilakukan oleh

$28 \quad$ Pasal 84 ayat (2) Undang-Undang Nomor 31 Tahun 2004 Tentang Perikanan (Lembaran Negara Republik Indonesia Tahun 2004 Nomor 118) jo Undang-Undang Nomor 45 Tahun 2009 Tentang Perubahan Atas Undang-Undang Nomor 31 Tahun 2004 Tentang Perikanan (Lembaran Negara Republik Indonesia Tahun 2009 Nomor 154).

29 Pasal 84 ayat (3) Undang-Undang Nomor 31 Tahun 2004 Tentang Perikanan (Lembaran Negara Republik Indonesia Tahun 2004 Nomor 118) jo Undang-Undang Nomor 45 Tahun 2009 Tentang Perubahan Atas Undang-Undang Nomor 31 Tahun 2004 Tentang Perikanan (Lembaran Negara Republik Indonesia Tahun 2009 Nomor 154).

30 Pasal 84 ayat (4) Undang-Undang Nomor 31 Tahun 2004 Tentang Perikanan (Lembaran Negara Republik Indonesia Tahun 2004 Nomor 118) jo Undang-Undang Nomor 45 Tahun 2009 Tentang Perubahan Atas Undang-Undang Nomor 31 Tahun 2004 Tentang Perikanan (Lembaran Negara Republik Indonesia Tahun 2009 Nomor 154).

31 Rudy Satriyo Mukantardjo, dkk, Loc.cit.

32 Rudy Satriyo Mukantardjo, dkk, Loc.cit.

33 Ibid. 
korporasi, tuntutan dan sanksi pidananya dijatuhkan terhadap pengurusnya, dan pidana dendanya ditambah sepertiga dari pidana yang dijatuhkan". Dengan rumusan demikian, meskipun dikatakan bahwa korporasi dapat melakukan pidana, tetapi korporasi tidak dapat dijatuhi pidana. Pada dasarnya konsep tersebut adalah perkembangan tahap kedua dari pertanggungjawaban korporasi. ${ }^{34} \mathrm{Hal}$ ini menjadi kemunduran bagi politik hukum pidana perikanan dengan politik hukum pidana nasional. Pidana hukum nasional dalam perkembangannya sudah memasukkan korporasi sebagai entitas yang dapat melakukan perbuatan pidana, sekaligus yang dapat dijatuhi pidana. ${ }^{35}$ Dalam hal ini, menjadi tidak begitu maksimal.

Hal ini akan mengurangi koherensi Peraturan Nasional dengan Poin 21 IPOA-IUU. Poin 21 IPOA-IUU merekomendasikan bahwa setiap negara wajib memastikan bahwa sanksi terhadap kegiatan IUU Fishing cukup memiliki efek jera untuk mencegah, menanggulangi, dan memberantas IUU Fishing secara efektif dan menghilangkan keuntungan ekonomi bagi pelaku IUU Fishing. ${ }^{36}$ Namun, dalam Pasal 101 UU Perikanan yang menyatakan "dalam hal tindak pidana perikanan dilakukan oleh korporasi, tuntutan dan sanksi pidananya dijatuhkan terhadap pengurusnya, dan pidana dendanya ditambah sepertiga dari pidana yang dijatuhkan". Untuk itu UndangUndang perikanan belum menyentuh korporasi sebagai subjek hukum. Berdasarkan Pasal 4 ayat (1) Peraturan Mahkamah Agung Nomor 11 Tahun 2016 tentang Tata Cara
Pelaksanaan Pertanggungjawaban Pidana Korporasi, "Korporasi dapat dimintakan pertanggungjawaban pidana sesuai dengan ketentuan pidana Korporasi dalam undangundang yang mengatur tentang Korporasi." Oleh karena itu, pada dasarnya Pasal 101 ini hanya dapat menjerat Pengurus dan bukan korporasi. Hal ini menunjukkan salah satu inkoherensi dengan Rencana Aksi Internasional IUUF. Dalam hal ini korporasi yang tidak dapat dijatuhi pidana akan mengurangi efek jera bagi korporasi yang bersangkutan. Oleh karena itu, UU Perikanan harus dirubah dengan salah satu perubahannya dalam pertanggungjawaban korporasi.

Selain berbicara mengenai pertanggungjawaban korporasi, sanksi pidana dalam UU perikanan telah menunjukan perkembangan terkait sanksi pidana. UU Perikanan memberikan sanksi yang jauh lebih tegas dari UU sebelumnya dengan menetapkan Pidana Penjara terberat pada 10 Tahun Penjara dan Denda terberat hingga $20 \mathrm{M}$, sedangkan UU sebelumnya hanya mencantumkan denda 100 juta rupiah. ${ }^{37} \mathrm{Hal}$ ini sejalan dengan Poin 21 IPOA-IUU dimana negara-negara anggota diwajibkan memberikan ketegasan sanksi untuk meningkatkan pemberantasan pidana di bidang perikanan. Pasal 84 adalah salah satu ketentuan pidana yang menunjukkan bagaimana sanksi diberikan dengan tegas kepada subjek hukum tertentu. Sistem pemidanaan dalam UU Perikanan adalah menggunakan sistem kumulatif dimana dua pidana pokok dijatuhkan, yakni Penjara dan Denda dimana dalam rumusan delik

Eddy O.S. Hiariej, Prinsip-Prinsip Hukum Pidana, (Yogyakarta, Cahaya Atma Pustaka 2014), hlm 67.

Ibid.

36 Poin 21 International Plan of Action to Prevent, Deter, and Eliminate Illegal, Unreported, and Unregulated Fishing

37 Koesrianti, Op.cit., hlm. 397. 
dihubungkan dengan kata 'dan'. Dengan menggunakan sistem indeterminate sentence dengan ancaman pidana maksimum. Pasal 84 ayat 1 UU perikanan memberikan sanksi maksimal 6 tahun penjara dan maksimum denda 1,2 miliyar. Pasal 84 ayat 2, 3, dan 4 memberikan ancaman pidana lebih tinggi ketika melibatkan subjek hukum tertentu yakni maksimal penjara 10 Tahun dengan denda yang sama.

Pasal 84 pada dasarnya dapat dikategorikan sebagai Illegal Fishing sebagaimana termaktub dalam Poin 3.1.2 IPOA-IUU. Poin tersebut menyatakan bahwa salah satu perbuatan Illegal Fishing adalah kapal berbendera yang memiliki hak melakukan penangkapan ikan di wilayah negara bersangkutan, tetapi menggunakan cara-cara yang dilarang. ${ }^{38}$ Pasal 84 UU perikanan mengatur kepada kapal dengan bendera apapun yang melakukan pembudayaan dan/atau penangkapan ikan menggunakan bahan kimia, bahan biologis, bahan peledak, alat dan/atau cara, dan/ atau bangunan yang dapat merugikan dan/ atau membahayakan kelestarian sumber daya ikan dan/ atau lingkungannya. ${ }^{39}$ Pasal 84 menunjukkan komitmen yang lebih kuat dimana penangkapan dan pembudidayaan perikanan yang dilakukan dengan cara ilegal (illegal fishing) merupakan perbuatan pidana di Indonesia. Dalam hal ini terdapat koherensi.
Kejahatan di bidang perikanan lainnya diatur dalam Pasal 88 UU Perikanan yang mengatur tentang perbuatan "memasukkan, megeluarkan, mengadakan, mengedarkan, dan/atau memelihara ikan yang merugikan masyarakat, pembudidayaan ikan, sumber daya ikan, dan/atau lingkungan sumber daya ikan ke dalam dan/atau ke luar wilayah pengelolaan perikanan Republik Indonesia." ${ }^{40} \mathrm{Hal}$ ini paling tidak berkaitan dengan Unreported Fishing sebagaimana direkomendasikan dalam poin 3.2 IPOA-IUU yang menyatakan bahwa Unreported Fishing dapat diartikan sebagai perbuatan tidak melaporkan atau salah melaporkan kepada otoritas nasional yang melanggar hukum nasional dan perbuatan di wilayah organisasi perikanan regional yang tidak dilaporkan pada organisasi tersebut. ${ }^{41}$ Pasal 88 menyiratkan tentang pelaporan tersebut, namun pasal tersebut tidak mengaitkan secara spesifik berkaitan dengan mekanisme pelaporan. Oleh karena itu, koherensi dalam pengaturan unreported fishing dalam UU Perikanan tidak optimal.

Selain itu, Indonesia tergabung dalam Western and Central Pacific Fisheries Commission (WCPFC) sebagai Regional Fisheries Management Organization di wilayah barat dan tengah samudra pasifik. Dalam hal ini UU Perikanan tidak mengatur secara spesifik mengenai dalam hal apa

38 Poin 3.1.2 International Plan of Action to Prevent, Deter, and Eliminate Illegal, Unreported, and Unregulated Fishing.

39 Pasal 84 Undang-Undang Nomor 31 Tahun 2004 Tentang Perikanan (Lembaran Negara Republik Indonesia Tahun 2004 Nomor 118) jo Undang-Undang Nomor 45 Tahun 2009 Tentang Perubahan Atas Undang-Undang Nomor 31 Tahun 2004 Tentang Perikanan (Lembaran Negara Republik Indonesia Tahun 2009 Nomor 154).

40 Pasal 88 Undang-Undang Nomor 31 Tahun 2004 Tentang Perikanan (Lembaran Negara Republik Indonesia Tahun 2004 Nomor 118) jo Undang-Undang Nomor 45 Tahun 2009 Tentang Perubahan Atas Undang-Undang Nomor 31 Tahun 2004 Tentang Perikanan (Lembaran Negara Republik Indonesia Tahun 2009 Nomor 154).

41 Poin 3.2 International Plan of Action to Prevent, Deter, and Eliminate Illegal, Unreported, and Unregulated Fishing. 
kapal berbendera negara Indonesia harus melaporkan atau berkomunikasi dengan WCPFC. Dalam hal ini sekali lagi ditemukan kurangnya harmonisasi IPOA-IUU dengan UU Perikanan. Hal ini erat juga kaitannya dengan kapal berbendera negara Indonesia di laut lepas yang tidak diatur dalam UU Perikanan.

Terdapat 3 jenis kejahatan di bidang perikanan lainnya yang saling berkaitan, yakni Pasal 92, 93, dan 94 UU Perikanan. Ketiga jenis kejahatan ini berkaitan dengan izin di bidang perikanan, yakni SIUP, SIPI, dan SIKPI. SIUP atau Surat izin usaha perikanan adalah izin tertulis yang harus dimiliki perusahaan perikanan untuk melakukan usaha perikanan dengan menggunakan sarana produksi yang tercantum dalam izin tersebut. ${ }^{42}$ Sedangkan SIPI atau Surat izin penangkapan ikan adalah izin tertulis yang harus dimiliki setiap kapal perikanan untuk melakukan penangkapan ikan yang merupakan bagian tidak terpisahkan dari SIUP. Terakhir, SIKPI atau Surat izin kapal pengangkut ikan adalah izin tertulis yang harus dimiliki setiap kapal perikanan untuk melakukan pengangkutan ikan. Pasal 92 mengatur perbuatan pidana bagi "setiap orang' yang dengan "sengaja" melakukan usaha perikanan tanpa SIUP. ${ }^{43}$ Kemudian, Pasal 93 UU Perikanan mengatur perbuatan pidana bagi "setiap orang" yang dengan kapal penangkap ikan berbendera Indonesia atau asing melakukan penangkapan ikan di Wilayah Perairan Perikanan Negara Republik Indonesia dan Zona Ekonomi Eksklusif Indonesia tanpa SIPI atau dengan menggunakan SIPI Palsu. ${ }^{44}$ Dalam hal ini tidak terdapat pengaturan mengenai laut lepas dan mengatur hubungan izin dengan WCPFC. Kemudian Pasal 94 mengatur mengenai kapal pengangkut yang mengangkut ikan tanpa SIKPI. ${ }^{45}$ Ketiga jenis kejahatan yang berkaitan dengan Izin Perikanan termasuk dalam Illegal Fishing. Hal tersebut termasuk ke dalam Poin 3.1.1. IPOA-IUU yang mengatur salah satu bentuk Illegal Fishing adalah "fishing conducted by national or foreign vessels in waters under the jurisdiction of a State, without the permission of that State." 46 Dalam hal ini IPOA-IUU menyiratkan bahwa negara diberi kewenangan penuh untuk memberikan izin kepada negara lain untuk melakukan penangkapan ikan dan bahkan kapal berbendera negara tetap harus mendapatkan izin dari negara yang memiliki wilayah tersebut.

Melihat konsep dalam kejahatan di bidang perikanan beberapa poin yang menjadicatatan adalah Unregulated Fishing sebagaimana diatur dalam Poin 3.3. dalam hal ini jelas karena

42 Pasal 1 angka 16 Undang-Undang Nomor 31 Tahun 2004 Tentang Perikanan (Lembaran Negara Republik Indonesia Tahun 2004 Nomor 118) jo Undang-Undang Nomor 45 Tahun 2009 Tentang Perubahan Atas Undang-Undang Nomor 31 Tahun 2004 Tentang Perikanan (Lembaran Negara Republik Indonesia Tahun 2009 Nomor 154).

43 Pasal 92 Undang-Undang Nomor 31 Tahun 2004 Tentang Perikanan (Lembaran Negara Republik Indonesia Tahun 2004 Nomor 118) jo Undang-Undang Nomor 45 Tahun 2009 Tentang Perubahan Atas Undang-Undang Nomor 31 Tahun 2004 Tentang Perikanan (Lembaran Negara Republik Indonesia Tahun 2009 Nomor 154).

44 Pasal 93 Undang-Undang Nomor 31 Tahun 2004 Tentang Perikanan (Lembaran Negara Republik Indonesia Tahun 2004 Nomor 118) jo Undang-Undang Nomor 45 Tahun 2009 Tentang Perubahan Atas Undang-Undang Nomor 31 Tahun 2004 Tentang Perikanan (Lembaran Negara Republik Indonesia Tahun 2009 Nomor 154).

45 Pasal 94 Undang-Undang Nomor 31 Tahun 2004 Tentang Perikanan (Lembaran Negara Republik Indonesia Tahun 2004 Nomor 118) jo Undang-Undang Nomor 45 Tahun 2009 Tentang Perubahan Atas Undang-Undang Nomor 31 Tahun 2004 Tentang Perikanan (Lembaran Negara Republik Indonesia Tahun 2009 Nomor 154).

46 Poin 3.1.1. International Plan of Action to Prevent, Deter, and Eliminate Illegal, Unreported, and Unregulated Fishing. 
Unregulated Fishing berkaitan dengan kapal tanpa bendera atau kapal dengan bendera negara yang bukan merupakan anggota regional fisheries management organization (RFMO). Seharusnya UU Perikanan mengatur hal tersebut sehingga sebagai anggota WCPFC indonesia dapat berkontribusi dalam penegakan hukum perikanan di laut lepas.

\section{c. Koherensi Hukum Formil}

Berbicara mengenai hukum pidana formil tentu merupakan hal yang sangat luas dan komprehensif sebagaimana termaktub dalam suatu sistem peradilan pidana. Hal ini dimulai dari tahapan penyelidikan, penyidikan, penuntutan, pemeriksaan di pengadilan, dan pelaksanaan putusan pengadilan yang berkekuatan hukum tetap. Dalam sub bab ini, ada beberapa kekhususan hukum acara pidana di bidang perikanan yang akan dikaji, yakni di bidang pengawasan, alat bukti, dan pengadilan perikanan.

Pengawasan perikanan diatur secara khusus pada Bab XII UU Perikanan. Bab ini termasuk sebagai bab yang mendapatkan paling banyak perubahan oleh UndangUndang Nomor 45 Tahun 2009. Pasal 66 ayat 1 UU Perikanan menyatakan secara tegas pengawasan perikanan dilakukan oleh pengawas perikanan. ${ }^{47}$ Tugas inti dari pengawas perikanan adalah untuk mengawasi pelaksanaan peraturan perundangundangan di bidang perikanan agar berjalan sebagaimana mestinya. ${ }^{48}$ Pengawas perikanan melaksanakan tugasnya di seluruh wilayah perairan. ${ }^{49}$ Dalam melaksanakan tugasnya pengawas perikanan juga diberikan kewenangan melakukan berbagai upaya paksa. ${ }^{50}$ Serta dalam melaksanakan tugasnya pengawas perikanan dapat dilengkapi dengan kapal pengawas perikanan, senjata api, dan/ atau alat pengaman diri. ${ }^{51}$

Selain kewenangan upaya paksa tersebut, kapal pengawas perikanan juga diberikan kewenangan yang sangat besar. Kapal pengawas perikanan dapat menghentikan, memeriksa, membawa, dan menahan kapal yang diduga atau patut diduga melakukan pelanggaran di wilayah pengelolaan perikanan Negara Republik Indonesia ke

$47 \quad$ Pasal 66 ayat 1 Undang-Undang Nomor 31 Tahun 2004 Tentang Perikanan (Lembaran Negara Republik Indonesia Tahun 2004 Nomor 118) jo Undang-Undang Nomor 45 Tahun 2009 Tentang Perubahan Atas Undang-Undang Nomor 31 Tahun 2004 Tentang Perikanan (Lembaran Negara Republik Indonesia Tahun 2009 Nomor 154).

48 Pasal 66 ayat 2 Undang-Undang Nomor 31 Tahun 2004 Tentang Perikanan (Lembaran Negara Republik Indonesia Tahun 2004 Nomor 118) jo Undang-Undang Nomor 45 Tahun 2009 Tentang Perubahan Atas Undang-Undang Nomor 31 Tahun 2004 Tentang Perikanan (Lembaran Negara Republik Indonesia Tahun 2009 Nomor 154).

49 Pasal 66B ayat 1 Undang-Undang Nomor 31 Tahun 2004 Tentang Perikanan (Lembaran Negara Republik Indonesia Tahun 2004 Nomor 118) jo Undang-Undang Nomor 45 Tahun 2009 Tentang Perubahan Atas Undang-Undang Nomor 31 Tahun 2004 Tentang Perikanan (Lembaran Negara Republik Indonesia Tahun 2009 Nomor 154).

50 Pasal 66C ayat 1 Undang-Undang Nomor 31 Tahun 2004 Tentang Perikanan (Lembaran Negara Republik Indonesia Tahun 2004 Nomor 118) jo Undang-Undang Nomor 45 Tahun 2009 Tentang Perubahan Atas Undang-Undang Nomor 31 Tahun 2004 Tentang Perikanan (Lembaran Negara Republik Indonesia Tahun 2009 Nomor 154).

51 Pasal 66C ayat 2 Undang-Undang Nomor 31 Tahun 2004 Tentang Perikanan (Lembaran Negara Republik Indonesia Tahun 2004 Nomor 118) jo Undang-Undang Nomor 45 Tahun 2009 Tentang Perubahan Atas Undang-Undang Nomor 31 Tahun 2004 Tentang Perikanan (Lembaran Negara Republik Indonesia Tahun 2009 Nomor 154). 
pelabuhan terdekat untuk pemrosesan lebih lanjut. ${ }^{52}$ Selain itu kapal pengawas juga dapat menenggelamkan kapal berbendera asing berdasarkan bukti permulaan yang cukup melakukan pelanggaran di bidang perikanan. ${ }^{53}$ Dengan konsep tersebut tentu pengawasan akan berjalan dengan sangat efektif, namun tidak terlepas dari kontroversi nasional maupun internasional. Pengawasan terhadap kapal berbendera negara asing merupakan hal yang juga harus dilakukan sangat efektif. ${ }^{54}$

Pengawasan ini juga termaktub dalam IPOA-IUU. Setiap negara wajib melakukan pemantauan, pengendalian, dan pengawasan (monitoring, control, and surveillance) secara komprehensif dan efektif terhadap kegiatan perikanan sejak penangkapan, pendaratan, sampai dengan pemasaran. ${ }^{55} \mathrm{Hal}$ tersebut sejalan dengan Code of Conduct for Responsible Fisheries (CCRF) 1995, dimana Pasal 6 angka 11 menyatakan Negara yang mengizinkan kapal-kapal ikan beroperasi di wilayahnya harus melakukan pengawasan yang efektif terhadap aktivitas kapal-kapal tersebut guna menjamin pelaksanaan. ${ }^{56}$ Dalam hal ini pengelolaan perikanan sangat penting dan harus dilaksanakan secara terpadu dan terarah, sehingga dalam hubungan inilah maka perlu diambil langkah-langkah untuk mengatur segi-segi kelestarian serta pengawasannya. ${ }^{57}$ Dalam hal ini terlihat jelas koherensi pidana nasional dan internasional dalam pengawasan perikanan. Dengan hal ini setiap negara dapat saling percaya bahwa setiap negara akan melakukan penegakan hukum.

Pengawasan menjadi pilar utama penegakan pidana perikanan. Salah satu penyebab banyaknya kasus IUU Fishing adalah masih lemahnya penegakan hukum dan pengawasan di Perairan Indonesia, terutama terhadap pengelolaan sumberdaya alam hayati laut, serta ketidaktegasan aparat dalam penanganan para pelaku illegal fishing. ${ }^{58}$ Terbukanya peluang bagi asing adalah salah satu sebab pengawasan akan

52 Pasal 69 ayat 3 Undang-Undang Nomor 31 Tahun 2004 Tentang Perikanan (Lembaran Negara Republik Indonesia Tahun 2004 Nomor 118) jo Undang-Undang Nomor 45 Tahun 2009 Tentang Perubahan Atas Undang-Undang Nomor 31 Tahun 2004 Tentang Perikanan (Lembaran Negara Republik Indonesia Tahun 2009 Nomor 154).

53 Pasal 69 ayat 4 Undang-Undang Nomor 31 Tahun 2004 Tentang Perikanan (Lembaran Negara Republik Indonesia Tahun 2004 Nomor 118) jo Undang-Undang Nomor 45 Tahun 2009 Tentang Perubahan Atas Undang-Undang Nomor 31 Tahun 2004 Tentang Perikanan (Lembaran Negara Republik Indonesia Tahun 2009 Nomor 154).

54 Pasal 18 ayat 2 Undang-Undang Nomor 31 Tahun 2004 Tentang Perikanan (Lembaran Negara Republik Indonesia Tahun 2004 Nomor 118) jo Undang-Undang Nomor 45 Tahun 2009 Tentang Perubahan Atas Undang-Undang Nomor 31 Tahun 2004 Tentang Perikanan (Lembaran Negara Republik Indonesia Tahun 2009 Nomor 154).

55 Poin 24 International Plan of Action to Prevent, Deter, and Eliminate Illegal, Unreported, and Unregulated Fishing.

56 Pasal 6 angka 11 Undang-Undang Nomor 31 Tahun 2004 Tentang Perikanan (Lembaran Negara Republik Indonesia Tahun 2004 Nomor 118) jo Undang-Undang Nomor 45 Tahun 2009 Tentang Perubahan Atas Undang-Undang Nomor 31 Tahun 2004 Tentang Perikanan (Lembaran Negara Republik Indonesia Tahun 2009 Nomor 154).

57 Rudy Satriyo Mukantardjo, dkk, Op.cit., hlm. 66.

58 Dina Sunyowati, "Dampak Kegiatan IUU-Fishing di Indonesia" (makalah disampaikan pada Seminar Nasional "Peran dan Upaya Penegak Hukum dan Pemangku Kepentingan Dalam Penanganan dan Pemberantasan IUU Fishing di Wilayah Perbatasan Indonesia", kerjasama Kementerian Luar Negeri Republik Indonesia dengan Universitas Airlangga Surabaya, 22 September 2014), hlm 1. 
menjadi lebih kompleks karena pengawas perikanan memiliki lebih banyak objek untuk diawasi. ${ }^{59}$

Khususnya di Zona Ekonomi Eksklusif Indonesia (ZEEI). Pada Pasal 29 ayat (1), dinyatakan bahwa usaha perikanan di wilayah pengelolaan perikanan, hanya boleh dilakukan oleh Warga Negara Indonesia atau Badan Hukum Indonesia. Selanjutnya pada ayat (2), kecuali terdapat ketentuan sebagaimana dimaksud pada ayat (1) diberikan kepada orang atau badan hukum asing yang melakukan penangkapan ikan di ZEE. ${ }^{60}$ Kerugian yang didapat akibat pelanggaran pidana perikanan mengakibatkan tingkat kerugian perikanan sekitar 25 persen dari total potensi perikanan yang dimiliki Indonesia sebesar 1,6 juta ton per tahun. ${ }^{61}$ Kondisi perikanan di dunia ini tidak berbeda jauh dengan kondisi di Indonesia. Namun, dengan kondisi tersebut paling tidak Kementrian Kelautan dan Perikanan telah melakukan pengawasan dan melakukan penangkapan terhadap 89 Kapal Asing dan 95 Kapal Ikan Indonesia, sehingga bisa menyelamatkan kerugian negara atas sumber daya hayati perikanan sebesar 439,6 Miliar Rupiah. ${ }^{62}$
Dalam hal ini terlihat dengan koherensi antara pidana nasional dan internasional maka dapat dicapai perlindungan yang optimal terhadap sumber daya hayati perikanan melalui mekanisme pengawasan. Namun, terdapat kelemahan dalam hukum nasional. Hukum nasional belum mengatur mengenai kerjasama pengawasan perikanan terhadap penangkapan di laut lepas.

Selain berbicara mengenai Pengawasan, Pengadilan Perikanan adalah konsep yang juga perlu dikaji secara spesifik dalam koherensi dengan hukum internasional. Pasal 71 UU Perikanan adalah pasal yang membentuk Pengadilan Perikanan yang berwenang memeriksa, mengadili, dan memutus tindak pidana di bidang perikanan yang merupakan pengadilan khusus di bawah lingkup peradilan umum. ${ }^{63}$ Pada awal pembentukannya hanya dibentuk pada Pengadilan Negeri Jakarta Utara, Medan, Pontianak, Bitung, dan Tual. ${ }^{64}$ Namun, pengadilan lain dapat dibentuk sesuai dengan kebutuhan yang ditetapkan dengan Keputusan Presiden. ${ }^{65}$ Keputusan Presiden Nomor 6 Tahun 2014 kemudian menetapkan tiga Pengadilan Negeri lain untuk membentuk Pengadilan Khusus, yakni Pengadilan Negeri

59 Ibid.

60 Ibid.

61 Ibid, hlm 3.

62 Ibid, hlm 4.

63 Pasal 71 ayat 1 dan 2 Undang-Undang Nomor 31 Tahun 2004 Tentang Perikanan (Lembaran Negara Republik Indonesia Tahun 2004 Nomor 118) jo Undang-Undang Nomor 45 Tahun 2009 Tentang Perubahan Atas UndangUndang Nomor 31 Tahun 2004 Tentang Perikanan (Lembaran Negara Republik Indonesia Tahun 2009 Nomor 154).

64 Pasal 71 ayat 3 Undang-Undang Nomor 31 Tahun 2004 Tentang Perikanan (Lembaran Negara Republik Indonesia Tahun 2004 Nomor 118) jo Undang-Undang Nomor 45 Tahun 2009 Tentang Perubahan Atas Undang-Undang Nomor 31 Tahun 2004 Tentang Perikanan (Lembaran Negara Republik Indonesia Tahun 2009 Nomor 154).

65 Pasal 71 ayat 5 Undang-Undang Nomor 31 Tahun 2004 Tentang Perikanan (Lembaran Negara Republik Indonesia Tahun 2004 Nomor 118) jo Undang-Undang Nomor 45 Tahun 2009 Tentang Perubahan Atas Undang-Undang Nomor 31 Tahun 2004 Tentang Perikanan (Lembaran Negara Republik Indonesia Tahun 2009 Nomor 154). 
Ambon, Sorong, dan Marauke. ${ }^{66}$ Pembentukan pengadilan perikanan ini diawali daerahdaerah yang berpotensi terjadi pelanggaran UU Perikanan. Selain itu dimaksudkan untuk menciptakan sistem yang komprehensif dalam menanggulangi tindak pidana di bidang perikanan.

Proses peradilan dalam Pengadilan Perikanan juga memiliki kekhususan, salah satunya dari proses penyidikan yang melibatkan tim yang terdiri dari Penyidikan tindak pidana di bidang perikanan dilakukan oleh Penyidik Pegawai Negeri Sipil Perikanan, Perwira TNI AL, dan Pejabat Polisi Negara Republik Indonesia. ${ }^{67}$ Selain penyidik, Hakim dalam Pengadilan Perikanan wajib berkomposisi 1 hakim karir dan 2 hakim ad-hoc. ${ }^{68}$ Pada dasarnya pembentukan kekhususan bagi penyidik yang merupakan PPNS Kementrian Kelautan dan Perikanan serta hakim adhoc yang memiliki ekspertise di bidang perikanan adalah didasarkan bahwa perangkat peradilan perikanan harus menguasai ilmu kelautan dan perikanan. ${ }^{69}$

Hal ini tentu sejalan dengan Poin 16 IPOA-IUU yang menyatakan bahwa Peraturan perundang-undangan nasional wajib mengatur semua aspek yang terkait dengan kegiatan IUU Fishing. ${ }^{70} \mathrm{Hal}$ ini menjadikan pengadilan perikanan adalah konsep wajib dalam penegakan hukum perikanan yang diatur secara khusus. Sekalipun IPOA-IUU tidak mengatur secara khusus mengenai pembentukan pengadilan perikanan, namun tersirat bahwa harus diciptakan sistem yang baik dalam menanggulangi kejahatan di bidang perikanan. Selain itu Poin 17 dari IPOA-IUU menyatakan peraturan perundang-undangan nasional wajib mengatur, antara lain mengenai standar pembuktian dan dimungkinkannya penggunaan bukti elektronik dan teknologi baru. ${ }^{71}$ Dalam hal ini UU perikanan tidak mengatur mengenai alat bukti elektronik. Namun UU perikanan mengatur hal yang cukup spesifik dibidang alat bukti, seperti pengaturan barang bukti dan alat bukti yang berhubungan dengan kapal mata pencaharian dan lain sebagainya. ${ }^{72}$ Dalam hal informasi dan dokumen elektronik tidak perlu diatur khusus, karena Pasal 5 Undang-Undang Nomor 11 Tahun 2008 tentang Informasi dan Transaksi Elektronik menyatakan bahwa Informasi dan

66 Keputusan Presiden Nomor 6 Tahun 2014 tentang Pembentukan Pengadilan Perikanan pada Pengadilan Negeri Ambon, Sorong, dan Marauke.

67 Pasal 73 ayat 1 Undang-Undang Nomor 31 Tahun 2004 Tentang Perikanan (Lembaran Negara Republik Indonesia Tahun 2004 Nomor 118) jo Undang-Undang Nomor 45 Tahun 2009 Tentang Perubahan Atas Undang-Undang Nomor 31 Tahun 2004 Tentang Perikanan (Lembaran Negara Republik Indonesia Tahun 2009 Nomor 154).

68 Pasal 78 ayat 1 Undang-Undang Nomor 31 Tahun 2004 Tentang Perikanan (Lembaran Negara Republik Indonesia Tahun 2004 Nomor 118) jo Undang-Undang Nomor 45 Tahun 2009 Tentang Perubahan Atas Undang-Undang Nomor 31 Tahun 2004 Tentang Perikanan (Lembaran Negara Republik Indonesia Tahun 2009 Nomor 154).

69 Rudy Satriyo Mukantardjo, dkk, Op.cit., hlm. 60.

70 Poin 16 International Plan of Action to Prevent, Deter, and Eliminate Illegal, Unreported, and Unregulated Fishing.

71 Poin 17 International Plan of Action to Prevent, Deter, and Eliminate Illegal, Unreported, and Unregulated Fishing.

72 Pasal 76 Undang-Undang Nomor 31 Tahun 2004 Tentang Perikanan (Lembaran Negara Republik Indonesia Tahun 2004 Nomor 118) jo Undang-Undang Nomor 45 Tahun 2009 Tentang Perubahan Atas Undang-Undang Nomor 31 Tahun 2004 Tentang Perikanan (Lembaran Negara Republik Indonesia Tahun 2009 Nomor 154). 
Dokumen Elektronik adalah perluasan alat bukti yang sah. ${ }^{73}$

Dalam halinijelas bahwaterdapatkoherensi antara hukum nasional dan internasional dalam penanggulangan kejahatan di bidang perikanan. Namun, terdapat beberapa kekurangan yang perlu diperbaiki sehingga dapat mengoptimalkan penegakan hukum perikanan dan dapat memberikan manfaat yang besar bagi masyarakat.

\section{Reformulasi Peraturan di Bidang Perikanan}

Dari pembahasan pada sub bab pertama dapat diperhatikan bahwa peraturan perundang-undangan di bidang perikanan telah cukup koheren dengan hukum internasional, namun masih memiliki banyak kelemahan. Beberapa poin kelemahan itu adalah Pertama, tidak diaturnya unregulated dan unreported fishing dalam UU Perikanan, Kedua, tidak dapat bertanggungjawabnya korporasi, Ketiga, pengaturan yurisdiksi laut lepas, Keempat, kerjasama dalam WCPFC.

Dalam mengatur unreported fishing perlu terlebih dahulu diatur mengenai kewajiban bagi para pengusaha yang memiliki SIUP untuk melaporkan secara rutin jumlah tangkapannya dan pengawas perikanan berkewajiban untuk memeriksa kebenaran informasi tersebut. Dengan dibentuknya kewajiban tersebut maka perlu diatur sanksi pidana dalam hal terjadi pelanggaran terhadap kewajiban tersebut. Tidak hanya itu, pengaturan tersebut juga harus disinkronisasikan dengan kebijakan WCPFC dalam menerima laporan atas penangkapan di laut lepas. Dalam hal ini perlu diatur peran pengawas perikanan dalam hal tersebut. Dengan diaturnya secara komprehensif IUU Fishing maka akan mengurangi kerugian yang diderita oleh Indonesia. Selain itu, jika di negara Indonesia bukan merupakan kejahatan maka akan sangat sulit jika berhubungan dengan kapal berbendera negara asing dimana akan melanggar asas double criminality karena bukan merupakan kejahatan di Indonesia. Oleh karena itu, menjadi wajib untuk direformulasi UU Perikanan.

Selain berbicara tentang perbuatan pidana, pertanggungjawaban korporasi juga menjadi isu yang perlu dikaji. IPOAIUU dengan tegas menyatakan bahwa sanksi pidana harus juga dirasakan oleh pengusaha dan juga korporasinya. Dalam hal ini UU Perikanan telah membuka peluang bahwa perbuatan pidana dapat dilakukan oleh korporasi, namun hal ini tidak menjadikan korporasi dapat dipidana. Hal ini tentu tidak sesuai dengan rekomendasi IPOA-IUU. Oleh karena itu, perlu diatur mengenai sanksi yang dapat dijatuhkan terhadap korporasi, sehingga jika perbuatan korporasi tersebut adalah kejahatan perikanan, terdapat peluang untuk menutup korporasi tersebut.

Selain itu, yurisdiksi UU Perikanan yang sangat terbatas pada wilayah Indonesia memberikan kelemahan pada kerjasama dalam penanggulangan kejahatan perikanan di laut lepas. Dalam hal ini perlu direformulasi sesuai dengan IPOA-IUU dan arahan kebijakan WCPFC dalam menanggulangi kejahatan perikanan di laut lepas. Dengan tidak adanya pengaturan yang jelas, maka akan terjadi kesulitan penegakan hukum dalam menanggulangi kejahatan perikanan di laut

\footnotetext{
73 Pasal 5 Undang-Undang Nomor 11 Tahun 2008 tentang Informasi dan Transaksi Elektronik.
} 
lepas. Oleh karena itu, laut lepas harus dapat menjadi yurisdiksi Indonesia atau setidaktidaknya kerjasama Indonesia dengan negara tetangga dalam menghadapinya. Dengan ini sekaligus kerjasama dengan WCPFC perlu ditingkatkan sehingga daerah barat dan tengah asia pasifik memiliki kebijakan yang sama dalam penanganan kejahatan perikanan.

Pada dasarnya untuk melakukan reformasi ini, telah ada Keputusan Menteri Kelautan dan Perikanan Nomor KEP.50/MEN/2012 tentang Rencana Aksi. Kepmen tersebut merupakan landasan Aksi Nasional dalam menanggulangi Illegal, Unreported, and Unregulated Fishing. ${ }^{74}$ Dalam Keputusan Menteri tersebut paling tidak terdapat beberapa rencana aksi indonesia yang penting meliputi: ${ }^{75}$

1. melanjutkan proses ratifikasi FAO Compliance Agreement tahun 1993;

2. melanjutkan proses keanggotaan dalam WCPFC;

3. melanjutkan proses ratifikasi Port State Measures;

4. melanjutkan proses integrasi resolusi RFMOs ke dalam legislasi nasional;

5. aktif dalam kegiatan yang dilaksanakan RFMOs, termasuk melaksanakan resolusi dan peningkatan kapasitas;

6. memperbaharui authorized fishing vessel dan record of fishing vessel; dan

7. melengkapi peraturan perundangundangan dan pedoman pelaksanaan untuk implementasi instrumen internasional.

Dalam hal ini terlihat bahwa aksi nasional mensyaratkan ratifikasi sejumlah kovensi. Selain itu penguatan kerjasama dengan
WCPFC juga merupakan agenda penting dalam aksi nasional tersebut. Dengan adanya aksi nasional ini, seharusnya dapat mendukung reformulasi peraturan perundang-undangan di bidang perikanan. Dengan hal tersebut maka diharapkan sumber daya hayati perikanan dapat diperoleh dengan optimal.

\section{Penutup}

Koherensi hukum pidana nasional dan internasional dalam bidang perikanan merupakan suatu keniscayaan didasarkan pada pidana perikanan yang mengandung aspekaspek internasional dalam penegakkannya. Dalam hal ini koherensi hukum pidana materiil telah terlihat pada beberapa sisi, walaupun masih terdapat kekurangan dalam pengaturan unregulated and unreported fishing. Selain itu, dalam pidana formil pengawasan perikanan dan pengadilan perikanan adalah konsep khusus yang dibentuk untuk menanggulangi pidana perikanan secara lebih efektif.

Dengan adanya kekurangan dalam pengaturan UU Perikanan, perlu dibentuk pengaturan yang lebih dapat mengoptimalkan perlindungan sumber daya hayati di bidang perikanan. Beberapa hal yang perlu direformulasi adalah pengaturan Unreported and unregulated fishing, pengaturan pertanggungjawaban pidana korporasi, pengaturan yurisdiksi di laut lepas, dan peningkatan kerjasama dengan WCPFC. Dalam hal ini Keputusan Menteri Kelautan dan Perikanan Nomor KEP.50/MEN/2012 tentang Rencana Aksi cukup menjadi landasan untuk perbaikan peraturan perundang-undangan tersebut.

Diktum Kesatu Keputusan Menteri Kelautan dan Perikanan Nomor KEP.50/MEN/2012 tentang Rencana Aksi.

Keputusan Menteri Kelautan dan Perikanan Nomor KEP.50/MEN/2012 tentang Rencana Aksi 
Untuk meningkatkan optimalisasi perlindungan sumber daya hayati di bidang perikanan adalah dengan memperbaiki peraturan perundang-undangan di bidang perikanan. Namun hal tersebut tidak akan cukup, jika tidak ada penguatan penegakan hukum. Dalam hal ini penegakan hukum terhadap pidana perikanan dapat dikuatkan dengan membentuk lebih banyak pengadilan perikanan sehingga dapat menyentuh wilayah lain yang rawan disalahgunakan. Selain itu, penting juga untuk memberikan pelatihan khusus kepada penegak hukum dalam menanggulangi kejahatan dibidang perikanan. Dengan adanya perbaikan-perbaikan tersebut diharapkan dapat mengoptimalkan penegakan hukum pidana perikanan.

\section{Daftar Pustaka}

\section{Buku}

Atmasasmita, Romli, Sistem Peradilan Pidana (Jakarta, Kencana Jakarta. 2010)

Atmasasmita, Romli, Globalisasi dan Kejahatan Bisnis (Jakarta, Kencana, 2010)

Effendi, Erdianto, Hukum Pidana Indonesia Suatu Pengantar (Bandung, PT Refika Aditama, 2011).

Hamzah, Andi, "Beberapa Hal dalam Rancangan KUHAP", (Makalah, Pelatihan Hukum Pidana dan Kriminologi Indonesia Yogyakarta, 24 Februari 2014).

Hersutanto, Begi, Problematika Sinergi dalam Grand Design Nasional Kebijakan Keamanan Laut (Jakarta, CSIS, 2007)

Hiariej, Eddy O.S., Pengantar Hukum Pidana Internasional (Jakarta, Erlangga, 2009).

Hiariej, Eddy O.S, Prinsip-Prinsip Hukum Pidana (Yogyakarta, Cahaya Atma Pustaka, 2014).

Kordi K, Gufron H, Pengelolaan Perikanan Indonesia (Yogyakarta, Pustaka Baru Press, 2015)

Moeljatno, Asas-Asas Hukum Pidana (Jakarta Rineka Cipta, 2008)

Moeljatno, Kriminologi (Jakarta, Bina Aksara, 1986)
Mukantardjo, Rudy Satriyo, dkk, Analisis dan Evaluasi Hukum tentang Pengadilan Perikanan (BPHN, Jakarta. 2009)

Muladi, Kapita Selekta Sistem Peradilan Pidana (Semarang, Badan Penerbit UNDIP, 1995)

Prasetyo, Teguh, Hukum Pidana (Jakarta, PT Raja Grafindo Persada, 2011)

Reksodiputro, Mardjono, Kriminologi dan Sistem Peradilan Pidana (Jakarta, Pusat Pelayanan dan Pengabdian Hukum Universitas Indonesia, 1997)

Soekanto, Soerjono, Pengantar Penelitian Hukum (Jakarta, UI-Press, 2007)

Soekanto, Soekanto dan Sri Mamudji, Penelitian Hukum Normatif Suatu Tinjauan Singkat (Jakarta, Rajawali Press, 2001)

Soemitro, Ronny Hanitijo, Metodologi Penelitian Hukum dan Jurimetr (Jakarta, Ghalia Indonesia, 1994)

Subagyo, Joko, Hukum Laut Indonesia (Jakarta, Rineka Cipta, 2005)

Sudarto, Hukum dan Hukum Pidana (Bandung, Alumni, 2007)

Sudarto, Hukum Pidana dan Perkembangan Masyarakat (Bandung, Sinar Baru, 1983)

Suhaidi, 2004, Perlindungan terhadap Lingnkungan Laut dari Pencemaran yang Bersumber dari Kapal : Konsekwensi Penerapan Hak Pelayaran Internasional Melalui Perairan Indonesia (Jakarta, Pustaka Bangsa Press, 2004)

Supriadi, Hukum Perikanan di Indonesia (Jakarta, Sinar Grafika, 2011)

Syamsuddin, Aziz, Tindak Pidana Khusus (Jakarta, Sinar Grafika Offset, 2011)

\section{Makalah/Artikel/Prosiding/Laporan/Hasil Penelitian}

Ayu, Hanuring, "Government Policy Directions on Illegal Unreported Unregulated (IUU) Fishing in Indonesia", (Proceeding, Internationalization of Islamic Higher Education Institutions Toward Global Competitiveness, Semarang, 20-21 September 2018).

Edeson, William, Tools to Address IUU Fishing: The Current Legal Situation, Document AUS:IUU/2000/8, (2000), hlm 1-2

Hutajulu, Marudut, Alvi Syahrin dkk, "Analisis TerhadapPencurian Ikan Di Zona Ekonomi Ekslusif Indonesia Wilayah Pengelolaan Perikanan Republik Indonesia (Studi Putusan 
No: 03/Pid.Sus.P/2012/PN.MDN)", USU Law Journal, Vol.II-No.1, 230-247, Februari 2014.

Isnurhadi, M. Rizqi, "Sekuritisasi Illegal, Unreported, Unregulated Fishing (IUUF) di Perairan Indonesia di Era Pemerintahan Joko Widodo", Jurnal Hubungan Internasional, Volume X, No.2, Juli - Desember 2017.

Koesrianti, "Penindakan Illegal Fishing dan Perjanjian Bilateral dengan Negara Tetangga di Bidang Perikanan", Mimbar Hukum, Vol. 20, No. 2, Juni, 2008.

M.Dandha, Forum Koordinasi Penanganan Tindak Pidana di Bidang Perikanan, Forum Hukum, Vol. 4-2 2007,

Sunyowati, Dina, Dampak Kegiatan IUU-Fishing di Indonesia, (makalah disampaikan pada Seminar Nasional "Peran dan Upaya Penegak Hukum dan Pemangku Kepentingan Dalam Penanganan dan Pemberantasan IUU Fishing di Wilayah Perbatasan Indonesia". Kerjasama Kementerian Luar Negeri Republik Indonesia dengan Universitas Airlangga Surabaya, 22 September 2014).

The Economist Intelligence Unit N.A., Incorporated, Fishing trips; Indonesia's Marine Policy, 2015, The Economist, Vol.414, 8919, 3 Januari 2015.

\section{Internet}

Almutaqqi, Ibrahim, Indonesia and the problem of illegal fishing, http://www.thejakartapost. com/news/ 2014/04/05/indonesia-andproblem-illegal-fishing (diakses 5 Juli 2015).

Damang, Sejarah Hukum Perikanan, http://www. negarahukum.com/hukum/sejarah-hukumperikanan.html, (diakses 17 September 2015). NOAA Fisheries, "Illegal, Unreported, and Unregulated Fishing", www.nfms.noaa.gov/ ia/iuu.
Santoso, Jodi, Sambutan Ketua MA Pada Peresmian Peradilan Perikanan, http://jodisantoso. blogspot.co.id/2007/10/sambutan-ketua-mapada-peresmian.html, (diakses 24 September 2015).

Shrift, Fresh, Kelebihan, Kekurangan dan Revisi UU No. 31 Tahun 2004 terhadap UU No. 45 Tahun 2009 serta Saran Penambahan Butir-butir dalam UU No. 45 tahun 2009, http://ilh4mfresh.blogspot.co.id/2012/06/kelebihankekurangan-dan-revisi-uu-no.html, (diakses 18 September 2015)

\section{Peraturan Perundang-Undangan}

Undang -Undang Dasar NRI Tahun 1945

Undang-Undang Nomor 31 Tahun 2004 Tentang Perikanan (Lembaran Negara Republik Indonesia Tahun 2004 Nomor 118)

Undang-Undang Nomor 45 Tahun 2009 Tentang Perubahan Atas Undang-Undang Nomor 31 Tahun 2004 Tentang Perikanan (Lembaran Negara Republik Indonesia Tahun 2009 Nomor 154)

Undang-Undang Nomor 48 Tahun 2009 tentang Kekuasaan Kehakiman (Lembaran Negara Tahun 2009 Nomor 157)

Keputusan Presiden Nomor 6 Tahun 2014 tentang Pembentukan Pengadilan Perikanan pada Pengadilan Negeri Ambon, Sorong, dan Marauke.

Keputusan Menteri No. KEP/50/MEN/2012 tentang Rencana Aksi Nasional Pencegahan dan Penanggulangan Illegal, Unreported, and Unregulated Fishing Tahun 2012-2016

Peraturan Mahkamah Agung Nomor 1 Tahun 2007 United Nations Convention on Law of Sea 1982 International Plan of Action to Prevent, Deter, and Eliminate Illegal, Unreported, and Unregulated Fishing. 